\title{
Pengendalian Kualitas Produk Kertas Koran di PT. Adiprima Suraprinta Menggunakan Diagram Kendali Multivariat
}

\author{
Nafilah Faradiba, Agus Suharsono dan Ni Luh Putu Satyaning Pradnya Paramita \\ Departemen Statistika, Fakultas Matematika, Komputasi, dan Sains Data, \\ Institut Teknologi Sepuluh Nopember (ITS) \\ e-mail:pradnya@statistika.its.ac.id
}

\begin{abstract}
Abstrak-PT. Adiprima Suraprinta merupakan anak perusahaan dari Jawa Pos Group yang bergerak dibidang produksi kertas. Salah satu produk kertas yang paling banyak diproduksi yaitu jenis kertas koran newsprint 45 gsm. Pada penelitian ini, analisis pengendalian kualitas dilakukan menggunakan data pada bulan Januari - Maret 2017. Dua karakteristik kualitas yaitu opacity dan brightness saling memiliki hubungan. Kenaikan brightness akan berpengaruh terhadap penurunan opacity. Sehubungan dengan hal itu maka pada penelitian ini digunakan diagram kendali Multivariate Exponentially Weighted Moving Variance (MEWMV) dengan pengamatan individual untuk mendeteksi perubahan variabilitas proses. Sementara itu, untuk melakukan monitoring rata-rata proses produksi dilakukan dengan menggunakan diagram kendali Multivariate Exponentially Weighted Moving Average (MEWMA). Hasil yang didapatkan yaitu variabilitas proses produksi pada fase satu maupun fase dua terkendali secara statistik dengan pembobot optimum $\omega=0.2$ dan $\lambda=0.4$, namun rata-rata proses pada fase satu maupun fase dua belum terkendali secara statistik dengan pembobot optimum $\lambda=0.9$. Kapabilitas proses menggunakan indeks MPpk menunjukkan proses tidak kapabel. Nilai MPpk pada fase satu sebesar 0.875 dan pada fase dua sebesar 0.92 menunjukkan bahwa presisi dan akurasi proses tidak baik.
\end{abstract}

Kata Kunci-Brightness, Kertas Koran, MEWMA, MEWMV, Opacity.

\section{PENDAHULUAN}

TNDUSTRI pulp dan kertas merupakan salah satu industri Iyang memegang peranan penting bagi perekonomian Indonesia. Hingga September 2016, peranan industri pulp dan kertas dalam perolehan devisa sebesar USD 3,79 miliar atau menduduki peringkat ke-7 sebagai penyumbang devisa terbesar dari sektor non migas. Industri pulp dan kertas juga menyerap lebih kurang 260.000 tenaga kerja langsung dan 1,1 juta tenaga kerja tidak langsung. Posisi industri pulp dan kertas nasional cukup terkemuka di dunia internasional. Saat ini Indonesia menempati peringkat ke-9 sebagai produsen pulp terbesar di dunia, sedangkan industri kertasnya menduduki peringkat ke- 6 [1].

PT. Adiprima Suraprinta merupakan anak perusahaan dari Jawa Pos Group yang bergerak dibidang produksi kertas dan telah memperoleh ISO 9001:2008 yang merupakan sertifikasi manufaktur kertas yang menggunakan pendekatan sistem manajemen mutu. Hasil produksi dari PT. Adiprima Suraprinta hingga saat ini digunakan untuk Jawa Pos dan anak perusahaannya, media cetak koran selain Jawa Pos dan untuk diekspor.
Pengendalian kualitas secara statistik sangat diperlukan untuk membantu perusahaan mengetahui kapabilitas proses produksi kertas. Produk kertas yang paling banyak diproduksi oleh PT. Adiprima Suraprinta yaitu jenis kertas koran 45 gsm. Dua karakteristik kualitas yaitu opacity dan brightness saling memiliki hubungan. Kenaikan brightness akan berpengaruh terhadap penurunan opacity. Sehubungan dengan hal itu maka diagram kendali multivariat sangat sesuai digunakan untuk dua variabel yang saling berhubungan tersebut. Diagram kendali Multivariate Exponentially Weighted Moving Variance (MEWMV) merupakan diagram kendali multivariat dengan pengamatan individual untuk mendeteksi perubahan variabilitas proses. Selain pengendalian pada variabilitas proses, pengendalian rata-rata proses produksi juga merupakan suatu hal yang penting untuk dilakuka menggunakan diagram kendali Multivariate Exponentially Weighted Moving Average (MEWMA) merupakan salah satu diagram kendali multivariat yang dapat mendeteksi perubahan rata-rata proses. Kelebihan dari diagram kendali ini adalah lebih sensitif terhadap pergeseran data, sehingga data yang tidak terkendali akan lebih cepat terdeteksi. Selain itu diagram kendali ini robust terhadap data yang tidak mengikuti distribusi normal multivariate [2].

Penelitian yang pernah dilakukan di pabrik kertas yang berkaitan dengan pengendalian kualitas pernah dilakukan oleh beberapa peneliti. Salah satunya Moses L. Singgih dan Renanda [3] melakukan penelitian tentang kualitas produk kertas dengan menggunakan pendekatan six sigma di pabrik kertas Y. Penelitian yang berkaitan dengan diagram kendali multivariat menggunakan Multivariate Exponentially Weighted Moving Average (MEWMA) dan Multivariate Exponentially Weighted Moving Variance (MEWMV) pernah dilakukan oleh beberapa peneliti. Salah satunya Devi Novitasari [4] melakukan penelitian tentang kualitas produk pakan ternak di PT. Japfa Comfeed Indonesia, Tbk Unit Gedangan untuk data multivariat.

\section{TINJAUAN PUSTAKA}

\section{A. Uji Independensi}

Variabel $X_{1}, X_{2}, \ldots, X_{p}$ dikatakan bersifat saling bebas (independent) jika matriks korelasi antar variabel membentuk matriks identitas. Untuk menguji kebebasan antar variabel ini dapat dilakukan uji Bartlett berikut [5]. 
Hipotesis :

$H_{0}: \rho=\mathbf{I}$ (variabel saling independen)

$H_{1}: \rho \neq \mathbf{I}($ variabel saling dependen $)$

jika nilai $X_{\text {hitung }}^{2} \leq X_{\left(\alpha, \frac{1}{2} p(p-1)\right)}^{2}$. Statistika uji dalam uji

Bartlett dituliskan dalam rumus berikut

$$
\chi^{2}=-\left(m-1-\frac{2 p+5}{6}\right) \ln |\boldsymbol{R}|
$$

Sehingga keputusan gagal tolak $\mathrm{H}_{0}$ yang berarti antar variabel bersifat saling bebas atau tidak ada korelasi jika nilai $X_{\text {hitung }}^{2} \leq X_{\left(\alpha, \frac{1}{2} p(p-1)\right)}^{2}$.

\section{B. Distribusi Normal Multivariat}

Pengujian normal multivariat dilakukan untuk mengetahui apakah data hasil pengamatan mengikuti distribusi normal multivariat atau tidak. Suatu pengamatan $x_{1}, x_{2} \ldots, x_{p}$ mempunyai distribusi normal multivariat dengan parameter $\mu$ dan $\Sigma$ jika memiliki fungsi densitas atau kepadatan peluang adalah sebagai berikut.

$f(x)=\frac{1}{(2 \pi)^{p / 2}|\Sigma|^{1 / 2}} e^{-\frac{1}{2}(x-\mu)^{\prime} \Sigma^{-1}(x-\mu)}$

pengujian distribusi normal multivariat dilakukan dengan pengujian Saphiro Wilk sebagai berikut.

$$
W=\frac{\left(\sum_{p=1}^{n} a_{p} \mathbf{X}_{\mathbf{p}}\right)^{2}}{\sum_{p}^{n}\left(\mathbf{X}_{\mathbf{p}}-\bar{x}\right)^{2}}
$$

dengan nilai $a_{p}$ adalah sebagai berikut.

$$
a_{p}=\frac{\mathbf{M}^{\mathbf{T}} \mathbf{V}^{-1}}{\left(\mathbf{M}^{\mathrm{T}} \mathbf{V}^{-1} \mathbf{V}^{-1} \mathbf{M}\right)^{1 / 2}}
$$

sehingga dikatakan mengikuti distribusi normal multivariat jika nilai statistik uji $W$ mendekati 1 , namun jika nilai statistik uji $W$ kecil atau jauh dari 1 maka dikatakan tidak mengikuti distribusi normal multivariat. Selain itu dapat dilihat jika $p$ value kurang dari $\alpha$, maka data tidak mengikuti distribusi normal multivariat [6].

\section{Multivariate Exponentially Weighted Moving Variance (MEWMV)}

Diagram kendali atau diagram kontrol MEWMV merupakan diagram kendali multivariat untuk memonitor variabilitas proses tanpa adanya asumsi terjadinya perubahan mean proses selama pengendalian berlangsung. Diagram kendali ini dibentuk dari persamaan berikut [7].

$$
\mathbf{V}_{\mathbf{n}}=\omega\left(\mathbf{x}_{\mathbf{n}}-\mathbf{y}_{\mathbf{n}}\right)\left(\mathbf{x}_{\mathbf{n}}-\mathbf{y}_{\mathbf{n}}\right)^{\prime}+(1-\omega) \mathbf{V}_{\mathbf{n}-\mathbf{1}}
$$

dimana $\omega$ merupakan nilai pembobot bernilai $0<\omega<1$ dan $\mathbf{V}_{\mathbf{0}}=\left(\mathbf{x}_{\mathbf{1}}-\mathbf{y}_{\mathbf{1}}\right)\left(\boldsymbol{x}_{\mathbf{1}}-\boldsymbol{y}_{\mathbf{1}}\right)^{\mathrm{T}} \cdot \mathrm{y}_{\mathrm{n}}$ merupakan estimasi untuk perubahan rata-rata proses pada waktu ke-n dengan persamaan berikut [8].

$$
\mathbf{y}_{\mathbf{n}}=\lambda \mathbf{x}_{\mathbf{n}}+(1-\lambda) \mathbf{y}_{\mathbf{n}-\mathbf{1}}
$$

untuk mendeteksi adanya perubahan dalam matriks kovarian harus didefinisikan :

$$
\mathbf{X}=\left[\begin{array}{c}
\mathbf{x}_{1} \\
\mathbf{x}_{2} \\
\vdots \\
\mathbf{x}_{\mathbf{n}}
\end{array}\right] \text { dengan } \mathbf{x}_{\mathbf{n}}=\left[\begin{array}{c}
\mathrm{x}_{1 \mathrm{n}} \\
\mathrm{x}_{2 \mathrm{n}} \\
\vdots \\
\mathbf{x}_{\mathrm{np}}
\end{array}\right] \text { dan } \mathrm{Y}=\left[\begin{array}{c}
\mathbf{y}_{\mathbf{1}} \\
\mathbf{y}_{\mathbf{2}} \\
\vdots \\
\mathbf{y}_{\mathbf{n}}
\end{array}\right]
$$

dimana $n$ merupakan banyaknya pengamatan dan $\mathrm{p}$ adalah banyaknya karakteristik kualitas. Matriks C merupakan matriks berukuran $\mathrm{n} \times \mathrm{n}$ dengan $\omega$ sebagai elemennya yang merupakan smoothing constant, dapat dituliskan :

$$
\mathbf{C}=\left[\begin{array}{ccccc}
(1-\omega)^{n-1} & 0 & 0 & \cdots & 0 \\
0 & \omega(1-\omega)^{n-2} & 0 & \cdots & 0 \\
0 & 0 & \ddots & 0 & 0 \\
\vdots & \vdots & 0 & \omega(1-\omega) & \vdots \\
0 & 0 & \cdots & 0 & \omega
\end{array}\right]
$$

Persamaan (15) dan (16) dapat diubah kedalam bentuk :

$$
\begin{gathered}
\mathbf{V}_{\mathbf{n}}=\sum_{i=1}^{n} \omega(1-\omega)^{n-i}\left(\mathbf{x}_{\mathbf{i}}-\mathbf{y}_{\mathbf{i}}\right)\left(\mathbf{x}_{\mathbf{i}}-\mathbf{y}_{\mathbf{i}}\right)^{\prime}+(1-\omega)^{n} \mathbf{V}_{\mathbf{0}} \\
\mathbf{y}_{\mathbf{n}}=\sum_{i=1}^{n} \lambda(1-\lambda)^{n-i} \mathbf{x}_{\mathbf{i}}
\end{gathered}
$$

Dengan memasukkan persamaan (19) ke dalam $\mathbf{x}_{\mathbf{i}}-\mathbf{y}_{\mathbf{i}}$ maka dapat dituliskan :

$$
\begin{aligned}
\mathbf{x}_{\mathbf{i}}-\mathbf{y}_{\mathbf{i}}= & (1-\lambda) \mathbf{x}_{\mathbf{i}}-\lambda(1-\lambda) \mathbf{x}_{\mathbf{i}-\mathbf{1}}-\cdots-\lambda(1-\lambda)^{i-1} \mathbf{x}_{\mathbf{1}} \\
& \mathrm{i}=1,2, \cdots, \mathrm{n}
\end{aligned}
$$

Jika persamaan (20) dituliskan dalam bentuk matriks adalah sebagai berikut.

$$
\begin{aligned}
& (\mathbf{X}-\mathbf{Y})=\left[\begin{array}{c}
\left(\mathbf{x}_{1}-\mathbf{y}_{1}\right)^{\mathbf{T}} \\
\left(\mathbf{x}_{2}-\mathbf{y}_{2}\right)^{\mathbf{T}} \\
\vdots \\
\left(\mathbf{x}_{n}-\mathbf{y}_{\mathbf{n}}\right)^{\mathrm{T}}
\end{array}\right] \\
& =\left[\begin{array}{cccc}
1-\lambda & 0 & \cdots & 0 \\
-\lambda(1-\lambda) & 1-\lambda & \cdots & 0 \\
\vdots & \vdots & \ddots & \vdots \\
-\lambda(1-\lambda)^{n-1} & \cdots & -\lambda(1-\lambda) & 1-\lambda
\end{array}\right] \times \\
& {\left[\begin{array}{c}
\mathbf{x}_{1}^{T} \\
\mathbf{x}_{2}^{T} \\
\vdots \\
\mathbf{x}_{n}^{T}
\end{array}\right]} \\
& =\left(\mathbf{I}_{\mathbf{n}}-\mathbf{M}\right) \mathbf{X}
\end{aligned}
$$

$\mathbf{I}_{\mathbf{n}}$ merupakan matrik identitas berukuran $\mathrm{n} \times \mathrm{n}$ yang dapat dituliskan,

$$
I_{n}=\left[\begin{array}{ccc}
1 & 0 & 0 \\
0 & \ddots & 0 \\
0 & 0 & 1
\end{array}\right]
$$

$M$ adalah matriks segitiga bawah berukuran $\mathrm{n} \times \mathrm{n}$ dengan $\lambda$ sebagai elemennya.

$$
\mathbf{M}=\left[\begin{array}{cccc}
\lambda & 0 & \cdots & 0 \\
\lambda(1-\lambda) & \lambda & \cdots & 0 \\
\vdots & \vdots & \ddots & \vdots \\
\lambda(1-\lambda)^{n-1} & \cdots & \lambda(1-\lambda) & \lambda
\end{array}\right]
$$

Persamaan (18) dapat diubah sebagai berikut.

$$
\mathbf{V}_{\mathbf{n}}=(\mathbf{X}-\mathbf{Y})^{\prime} \mathbf{C}(\mathbf{X}-\mathbf{Y})
$$

Dengan mensubtitusikan persamaan (11) ke dalam persamaan (12) maka dapat diperoleh,

$$
\begin{aligned}
\mathbf{V}_{\mathbf{n}} & =\mathbf{X}^{\prime}\left(\mathbf{I}_{\mathbf{n}}-\mathbf{M}\right)^{\prime} \mathbf{C}\left(\mathbf{I}_{\mathbf{n}}-\mathbf{M}\right) \mathbf{X} \\
& =\mathbf{X}^{\prime} \mathbf{Q} \mathbf{X}
\end{aligned}
$$

dimana $\mathrm{Q}$ adalah matriks bujur sangkar dengan ukuran $\mathrm{n} \times \mathrm{n}$

$$
\begin{aligned}
\mathbf{Q} & =\left(\mathbf{I}_{\mathbf{n}}-\mathbf{M}\right)^{\prime} \mathbf{C}\left(\mathbf{I}_{\mathbf{n}}-\mathbf{M}\right) \\
& =\left[\begin{array}{ccc}
\mathrm{q}_{11} & \cdots & \mathrm{q}_{1 \mathrm{n}} \\
\vdots & \ddots & \vdots \\
\mathrm{q}_{\mathrm{n} 1} & \cdots & \mathrm{q}_{\mathrm{nn}}
\end{array}\right] ; 1 \leq \mathrm{i} ; \mathrm{j} \leq \mathrm{n}
\end{aligned}
$$

dari persamaan (12) dapat dicari nilai $\operatorname{tr}\left(\mathbf{V}_{\mathbf{n}}\right)$ dengan persamaan berikut. 


$$
\begin{aligned}
\operatorname{tr}\left(\mathbf{V}_{\mathbf{n}}\right) & =\operatorname{tr}\left(\mathbf{X}^{\prime} \mathbf{Q X}\right) \\
& =\operatorname{tr}\left(\mathbf{Q} \mathbf{X} \mathbf{X}^{\prime}\right)
\end{aligned}
$$

$$
\begin{aligned}
\text { dengan, } & \mathbf{Q X X}^{\prime}=\left[\begin{array}{ccc}
\mathrm{q}_{11} & \cdots & \mathrm{q}_{1 \mathrm{n}} \\
\vdots & \ddots & \vdots \\
\mathrm{q}_{\mathrm{n} 1} & \cdots & \mathrm{q}_{\mathrm{nn}}
\end{array}\right] \\
& \times\left[\begin{array}{ccccc}
\sum_{k=1}^{p} x_{1 k} & x_{1 k} & \sum_{k=1}^{p} x_{1 k} x_{2 k} & \cdots & \sum_{k=1}^{p} x_{1 k} x_{n k} \\
\sum_{k=1}^{p} x_{1 k} x_{2 k} & \sum_{k=1}^{p} x_{2 k} x_{2 k} & \cdots & \sum_{k=1}^{p} x_{2 k} x_{n k} \\
\vdots & \vdots & \ddots & \vdots \\
\sum_{k=1}^{p} x_{1 k} x_{n k} & \sum_{k=1}^{p} x_{2 k} x_{n k} & \cdots & \sum_{k=1}^{p} x_{n k} x_{n k}
\end{array}\right]
\end{aligned}
$$

Sehingga dapat diketahui,

$$
\begin{aligned}
\operatorname{tr}\left(\mathbf{V}_{\mathbf{n}}\right)= & \sum_{j=1}^{n} q_{1 j}\left(\sum_{k=1}^{p} x_{1 k} x_{j k}\right)+\sum_{j=1}^{n} q_{2 j}\left(\sum_{k=1}^{p} x_{2 k} x_{j k}\right)+\cdots \\
& +\sum_{j=1}^{n} q_{n j}\left(\sum_{k=1}^{p} x_{n k} x_{j k}\right) \\
= & \sum_{i=1}^{k} \sum_{j=1}^{k} q_{i j}\left(\sum_{k=1}^{p} x_{i k} x_{j k}\right)
\end{aligned}
$$

Pada saat $\mathrm{p}=1$ maka persamaan $\operatorname{tr}\left(\mathbf{V}_{\mathbf{n}}\right)$ akan menjadi persamaan EWMV. Saat proses dalam keadaan terkendali dapat ditunjukkan perhitungan untuk mendapatkan $\mathrm{E}\left(\operatorname{tr}\left(\mathbf{V}_{\mathbf{n}}\right)\right.$.

$$
\begin{aligned}
\mathrm{E}\left[\operatorname{tr}\left(\mathbf{V}_{\mathbf{n}}\right)\right] & =\sum_{\mathrm{i}=1}^{\mathrm{n}} \mathrm{q}_{\mathrm{ii}} \mathrm{E}\left(\sum_{\mathrm{k}=1}^{\mathrm{p}} \mathrm{x}_{\mathrm{ik}}^{2}\right)+\sum_{\mathrm{i}=1}^{\mathrm{n}} \sum_{\mathrm{j} \neq \mathrm{i}}^{\mathrm{n}} \mathrm{q}_{\mathrm{ij}} \mathrm{E}\left(\sum_{\mathrm{k}=1}^{\mathrm{p}} \mathrm{x}_{\mathrm{ik}} \mathrm{X}_{\mathrm{jk}}\right) \\
& =\mathrm{p} \sum_{\mathrm{i}=1}^{\mathrm{n}} \mathrm{q}_{\mathrm{ii}} \\
& =\mathrm{p} \operatorname{tr}(\mathrm{Q})
\end{aligned}
$$

Nilai $E\left[\operatorname{tr}\left(\mathbf{V}_{\mathbf{n}}\right)\right]$ akan konvergen $\operatorname{ke} E\left(\mathbf{V}_{\mathbf{n}}\right)=\frac{2(1-\lambda)^{2} \Sigma}{2-\lambda}$ untuk $\mathrm{n} \rightarrow \infty$ dan $\operatorname{tr}\left(\mathbf{V}_{\mathbf{n}}\right)$ didapatkan dari persamaan.

$$
\begin{aligned}
\operatorname{Var}\left[\operatorname{tr}\left(\mathbf{V}_{\mathbf{n}}\right)\right] & =\operatorname{Var}\left[\sum_{i=1}^{\mathrm{n}} \mathrm{q}_{\mathrm{ii}} \sum_{\mathrm{k}=1}^{\mathrm{p}} \mathrm{x}_{\mathrm{ik}}^{2}+2 \sum_{\mathrm{i}=1}^{\mathrm{n}} \sum_{\mathrm{j}<\mathrm{i}}^{\mathrm{n}} \mathrm{q}_{\mathrm{ij}} \sum_{\mathrm{k}=1}^{\mathrm{p}} \mathrm{x}_{\mathrm{ik}} \mathbf{X}_{\mathrm{jk}}\right] \\
& =\sum_{\mathrm{i}=1}^{\mathrm{n}} \mathrm{q}_{\mathrm{ii}}^{2} \operatorname{Var}\left(\sum_{\mathrm{k}=1}^{\mathrm{p}} \mathrm{x}_{\mathrm{ik}}^{2}\right)+4 \sum_{\mathrm{i}=1}^{\mathrm{n}} \sum_{\mathrm{j}<\mathrm{i}}^{\mathrm{n}} \mathrm{q}_{\mathrm{ij}}^{2} \operatorname{Var}\left(\sum_{\mathrm{k}=1}^{\mathrm{p}} \mathrm{x}_{\mathrm{ik}} \mathrm{X}_{\mathrm{jk}}\right) \\
& =2 \mathrm{p} \sum_{\mathrm{i}=1}^{\mathrm{n}} \sum_{\mathrm{j}=1}^{\mathrm{n}} \mathrm{q}_{\mathrm{ij}}^{2}+4 \mathrm{p} \sum_{\mathrm{i}=1}^{\mathrm{n}} \sum_{\mathrm{j}<\mathrm{i}}^{\mathrm{n}} \mathrm{q}_{\mathrm{ij}}^{2} \\
& =2 \mathrm{p} \sum_{\mathrm{i}=1}^{\mathrm{n}} \sum_{\mathrm{j}=1}^{\mathrm{n}} \mathrm{q}_{\mathrm{ij}}^{2}
\end{aligned}
$$

Persamaan (15) akan menjadi BKA dan BKB yang memungkinkan untuk setiap $\mathrm{n}$ dan batas diagram kendalinya adalah :

$$
\mathrm{E}[\operatorname{tr}(\mathbf{V n})] \pm \mathrm{L} \sqrt{\operatorname{Var}[\operatorname{tr}(\mathbf{V n})]}=p \cdot \operatorname{tr}(\mathbf{Q}) \pm \mathrm{L} \sqrt{2 \mathrm{p} \sum_{i=1}^{n} \sum_{j=1}^{n} q_{i j}{ }^{2}}
$$

dimana $L$ adalah konstanta yang bergantung pada nilai $\omega$ dan $\lambda$ yang telah ditentukan sebelumnya.

\section{Multivariate Exponentially Weighted Moving Average (MEWMA)}

Diagram kendali ini digunakan untuk mendeteksi adanya perubahan mean proses.

$$
\begin{gathered}
\mathbf{Z}_{\mathbf{i}}=\lambda \mathbf{X}_{\mathbf{i}}+(1-\lambda) \mathbf{Z}_{\mathbf{i}-\mathbf{1}} \\
\mathbf{X}=\left[\begin{array}{c}
\mathbf{x}_{\mathbf{1}} \\
\mathbf{x}_{2} \\
\vdots \\
\mathbf{x}_{\mathbf{n}}
\end{array}\right] \text {, dimana } \mathbf{x}_{\mathrm{n}}=\left[\begin{array}{c}
\mathrm{x}_{1 \mathrm{n}} \\
\mathbf{x}_{2 \mathrm{n}} \\
\vdots \\
\mathbf{x}_{\mathrm{np}}
\end{array}\right]
\end{gathered}
$$

dimana $\lambda$ adalah pembobot yang bernilai $0 \leq \lambda \leq 1$ dan $\mathbf{Z}_{0}=\mathbf{0}$. Apabila tidak ada alasan pemilihan pembobot berbeda untuk masing masing karakteristik kualitas maka pembobot $\lambda_{1}=$ $\lambda_{2}=\cdots=\lambda_{p}=\lambda$. Titik pengamatan yang diplotkan di diagram kendali adalah :

$$
\mathrm{T}_{\mathrm{i}}^{2}=\mathbf{Z}_{\mathrm{i}}^{\prime} \Sigma_{\mathbf{Z}_{\mathrm{i}}}^{-1} \mathbf{Z}_{\mathrm{i}}
$$

Data dikatakan out of control ketika nilai $\mathrm{T}_{\mathrm{i}}^{2}$ lebih besar dari $\mathrm{h}_{4}$ (batas kendali atas). Matriks kovarian dari $\mathbf{Z}_{\mathbf{i}}$ adalah :

$$
\boldsymbol{\Sigma}_{\mathbf{Z}_{i}}=\frac{\lambda}{2-\lambda}\left[1-(1-\lambda)^{2 i}\right] \mathbf{\Sigma}
$$

Dengan batas kendali atas dan batas kendali bawah,

$\mathrm{BKA}=\mathrm{h}_{4}$

$\mathrm{BKB}=0$

\section{E. Analisis Kapabilitas Proses}

Kapabilitas proses merupakan suatu pengukuran yang digunakan untuk mengevaluasi keseluruhan proses. Indeks kapabilitas yang disarankan oleh Automotive Industry Action Group (AIAG) untuk proses dalam keadaan in control adalah $C_{p}$ dan $C_{p k}$, sedangkan untuk proses yang tidak dalam keadaan in control, digunakan indeks performance process $P_{p}$ dan $P_{p k}$. Perhitungan indeks $P_{p}$ dan $P_{p k}$ untuk data univariat adalah sebagai berikut

$$
\begin{gathered}
P_{P}=\frac{B S A-B S B}{6 s} \\
P_{P U}=\frac{B S A-\bar{x}}{3 s} \\
P_{P L}=\frac{\bar{x}-B S B}{3 s} \\
P_{P K}=\min \left\{P_{P U}, P_{P L}\right\}
\end{gathered}
$$

Keterangan :

$B S A=$ batas spesifikasi atas

$B S B=$ batas spesifikasi bawah

Analisis kapabilitas proses untuk data multivariat adalah sebagai berikut [9].

$$
\begin{gathered}
M P_{P}=\sum_{K=1}^{P} W_{k} P_{P}\left(X_{k}\right) \\
M P_{P K}=\sum_{K=1}^{P} W_{k} P_{P K}\left(X_{k}\right)
\end{gathered}
$$

keterangan:

$M P_{P}$ : Tingkat presisi data multivariat $M P_{P K}$ : Tingkat akurasi data multivariat 
$W_{k}$ merupakan pembobot dengan $\sum_{K=1}^{P} W_{k}=1$. Presisi adalah ukuran kedekatan antara satu pengamattan dengan pengamatan lain. Dan Akurasi adalah ukuran kedekatan hasil pengamatan dengan nilai target.

\section{F. Proses Produksi Kertas}

Salah satu produk yang paling banyak diproduksi di PT. Adiprima Suraprinta adalah kertas koran $45 \mathrm{gsm}$. Bahan baku yang digunakan untuk membuat kertas koran yaitu menggunakan kertas bekas (waste paper). Proses produksi kertas meliputi unit Stock Preparation dan unit Paper Machine. Sebelum dilakukan pengolahan bahan baku (waste paper) pada unit Stock Preparation dan unit Paper Machine, dilakukan proses pensortiran.

\section{METODOLOGI PENELITIAN}

\section{A. Sumber Data}

Data yang digunakan adalah data sekunder yang diperoleh dari departemen quality control pada PT. Adiprima Suraprinta. Pengambilan sampel kertas dilakukan pada setiap kali produksi kertas berlangsung yaitu per jam pada bagian unit paper machine setelah melalui mesin callendar sehingga dalam sehari terdapat 24 sampel dan dalam satu hari dibagi atas 3 shift kerja. Sampel yang digunakan dalam diagram kendali fase 1 pada tanggal 4-16 Januari 2017 dan tanggal 24-30 Januari 2017 yaitu sebanyak 480 data dan diagram kendali fase 2 pada tanggal 1-3 Februari, 11-12 Februari, 24-25 Februari 2017, 2-3 Maret dan 21-23 Maret 2017 sebanyak 288 data.

\section{B. Variabel Penelitian}

Variabel yang digunakan dalam penelitian ini adalah Brightness dan Opacity dengan batas spesifikasi sebagai berikut.

Tabel 1.

Batas Spesifikasi Masing-Masing Karakteristik Kulitas

\begin{tabular}{ccc}
\hline \hline Variabel & Karakteristik Kualitas & Batas Spesifikasi \\
\hline $\mathrm{X}_{1}$ & Brightness & $50-54 \%$ \\
\hline $\mathrm{X}_{2}$ & Opacity & Min $94 \%$ \\
\hline \hline
\end{tabular}

\section{Langkah Penelitian}

1. Merumuskan masalah dan tujuan penelitian

2. Mengambil data sekunder

3. Mendeskripsikan karakteristik masing-masing variabel dengan statistika deskriptif

4. Melakukan pengujian asumsi

Asumsi data berdistribusi normal multivariat dan adanya korelasi antara satu karakteristik kualitas dengan karakteristik kualitas yang lain.

5. Melakukan pengendalian proses produksi yang terdiri dari dua diagram kendali yaitu pengendalian variabilitas dan rata-rata proses

a. Diagram kendali MEWMV digunakan untuk variabilitas proses. Adapun tahapannya adalah sebagai berikut.

1. Membuat matriks $\mathrm{C}$ yang berukuran $\mathrm{n} \times \mathrm{n}$ dimana $\omega$ adalah diagonal utama dan merupakan nilai pembobot yang ditentukan sebelumnya.
2. Membuat matriks $\mathbf{M}$ yaitu matriks segitiga bawah dengan elemen $\lambda$.

3. Membuat matriks $I_{n}$ merupakan matriks identitas berukuran $\mathrm{n} \times \mathrm{n}$

4. Menghitung nilai $\mathrm{Q}$ untuk mendapatkan $\operatorname{tr}\left(\mathrm{V}_{\mathrm{n}}\right)$.

5. Menghitung $\operatorname{tr}\left(\mathrm{V}_{\mathrm{n}}\right)$ sesuai dengan persamaan (2.13).

6. Menghitung nilai $E\left(\operatorname{tr}\left(\mathrm{V}_{\mathrm{n}}\right)\right)$ dan $\operatorname{Var}\left(\operatorname{tr}\left(\mathrm{V}_{\mathrm{n}}\right)\right)$ sesuai dengan persamaan (2.14).

7. Menentukan batas kendali setiap pengamatan ke $n E\left[\operatorname{tr}\left(V_{n}\right)\right] \pm L \sqrt{\operatorname{Var}\left[\operatorname{tr}\left(V_{n}\right)\right]}$

b. Diagram kendali MEWMA untuk pengendalian rata-rata proses.

Adapun langkah-langkahnya adalah sebagai berikut.

1. Menetapkan nilai pembobot $\lambda, 0.1 \leq \lambda \leq 0.9$, dengan $\mathrm{h}_{4}$ yang sebelumnya telah ditentukan pada diagram kendali MEWMA

2. Menghitung matriks varian kovarian $\Sigma$.

3. Menghitung vektor MEWMA $Z_{i}$

4. Menghitung statistik MEWMA yaitu $T_{i}^{2}$

6. Melakukan pengendalian variabilitas dan rata-rata proses dengan diagram kontrol MEWMV dan MEWMA pada fase dua dengan pembobot optimal yang sudah didapatkan pada fase satu

7. Menganalisis kapabilitas proses

8. Membuat kesimpulan

\section{ANALISIS DAN PEMBAHASAN}

\section{A. Deskripsi Kualitas Produk Kertas Koran}

Untuk mengetahui gambaran umum tentang masing-masing karakteristik kualitas pada periode Januari hingga Maret 2017 maka diberikan deskripsi kualitas pada Tabel 2 berikut. Tabel 2.

Deskripsi Karakteristik Kualitas

\begin{tabular}{lllll}
\hline \hline Variabel & Mean & Varians & Minimum & Maximum \\
\hline Brightness (\%) & 51.919 & 0.665 & 50.00 & 55.810 \\
Opacity (\%) & 95.691 & 0.327 & 93.270 & 97.410 \\
\hline \hline
\end{tabular}

Berdasarkan Tabel 2. terlihat bahwa rata-rata presentase variabel brightness dan opacity adalah $51.919 \%$ dan $95.691 \%$. Jika dilihat dari rata-rata presentase tersebut, dapat dikatakan bahwa kedua nilai tersebut masih berada di dalam batas spesifikasi yang telah ditentukan perusahaan. Varians data variabel brightness sebesar 0.665 dan variabel opacity sebesar 0.327 . Nilai minimum dari presentase variabel brightness sebesar 50\%, \%, dimana nilai ini masih berada di dalam batas spesifikasi perusahaan. Sedangkan untuk nilai maksimum sebesar 55,810, nilai ini telah melebihi batas spesifikasi dari perusahaan yaitu $50-54 \%$. Nilai minimum opacity yang bernilai 93,270, dimana nilai ini berada dibawah standar spesifikasi perusahaan yaitu $94 \%$.

\section{B. Uji Dependensi antar Variabel}

Pemeriksaan dependensi antar variabel menggunakan uji Bartlett dengan tingkat signifikansi 0,05 ditunjukkan pada Tabel 3 berikut. 
Tabel 3

Output Uji Bartlett

\begin{tabular}{ccc}
\hline \hline Chi-Square & $d f$ & $P$-value \\
\hline 249,647 & 1 & 0.000 \\
\hline
\end{tabular}

Berdasarkan Tabel 3 didapatkan nilai chi-square sebesar 249,647 lebih besar dari nilai chi-square tabel sebesar 6.63490, sehingga dapat disimpulkan bahwa kedua variabel tersebut saling dependen. Selain itu, dapat dilihat dari $p$-value sebesar 0,000 , nilai tersebut lebih kecil dari tingkat signifikansi 0,05 sehingga dapat dikatakan bahwa kedua variabel saling berkorelasi.

\section{Distribusi Normal Multivariat}

Pemeriksaan asumsi normal multivariat dilakukan untuk kedua variabel karakteristik kualitas kertas koran yaitu brightness dan opacity. Berdasarkan hasil analisis yang telah dilakukan terhadap data didapatkan $p$-value sebesar 0.003395 , dimana nilai tersebut kurang dari tingkat signifikansi 5\%, maka dapat disimpulkan bahwa data karakteristik kualitas tidak mengikuti distribusi normal multivariat.

\section{Pengendalian Variabilitas dan Rata-Rata Proses}

Diagram kendali MEWMV digunakan untuk melakukan monitoring variabilitas proses sedangkan untuk pengendalian rata-rata proses dilakukan dengan menggunakan diagram kendali MEWMA. Pada penelitian ini data dibagi menjadi dua fase, dimana satu bulan pertama yaitu periode Januari 2017 digunakan untuk fase pertama sebanyak 480 data dan dua bulan selanjutnya yaitu Februari hingga Maret 2017 digunakan untuk fase kedua sebanyak 288 data. Pengendalian kualitas pada fase pertama dilakukan terlebih dahulu untuk mendapatkan nilai pembobot yang optimal. Pembobot optimal yang didapatkan pada fase pertama tersebut kemudian digunakan untuk monitoring proses pada fase kedua.

1) Pengendalian Variabilitas Proses Fase Satu

Pada penelitian ini digunakan pembobot $\omega$ dan $\lambda$ masingmasing kurang dari 0,4 karena menurut Huwang [7] nilai pembobot tersebut memberikan kinerja yang lebih baik untuk memonitoring variabilitas proses. Oleh karena itu dalam penelitian ini digunakan pembobot $\omega$ dan $\lambda$ yang kurang dari 0.4 yaitu $0.1,0.2,0.3$ dan 0.4 . Gambar 1 adalah hasil plot $\operatorname{tr}(\mathbf{V n})$ untuk nilai pembobot $\omega=0.2$ dan $\lambda=0.4$.Pemilihan pembobot terbaik yang digunakan untuk mendeteksi adanya pergeseran proses didasarkan pada jarak minimum antara nilai $\operatorname{tr}(\mathbf{V n})$ dan BKA serta batas kendali yang sempit. Berikut adalah hasil perhitungannya.

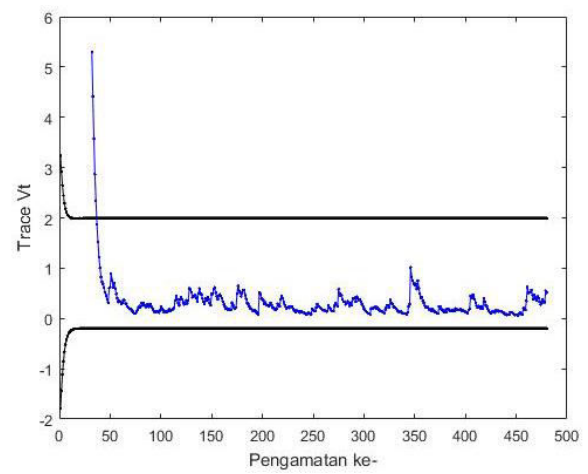

Gambar 1. Diagram MEWMV dengan $\omega=0.2$ dan $\lambda=0.4$.
Tabel 4

Hasil Perhitungan Selisih Max $\operatorname{Tr}(\mathrm{Vn})$ dengan BKA

\begin{tabular}{cccccc}
\hline \hline$\omega$ & $\lambda$ & $\mathrm{L}$ & Max $\operatorname{tr}(\mathrm{Vn})$ & $\mathrm{BKA}$ & Selisih \\
\hline 0.1 & 0.1 & 2.8725 & 9420.2 & 2.8383 & 9417.362 \\
0.1 & 0.2 & 2.8738 & 7443.1 & 2.3796 & 7440.72 \\
0.1 & 0.3 & 2.88 & 5698.6 & 1.9418 & 5696.658 \\
0.1 & 0.4 & 2.8838 & 4186.8 & 1.5263 & 4185.274 \\
0.2 & 0.1 & 3.4725 & 9420.2 & 3.6903 & 9416.51 \\
0.2 & 0.2 & 3.4775 & 7443.1 & 3.0976 & 7440.002 \\
0.2 & 0.3 & 3.485 & 5698.6 & 2.5314 & 5696.069 \\
$\mathbf{0 . 2}$ & $\mathbf{0 . 4}$ & $\mathbf{3 . 4 9 7 5}$ & $\mathbf{4 1 8 6 . 8}$ & $\mathbf{1 . 9 9 5 4}$ & $\mathbf{4 1 8 4 . 8 0 5}$ \\
0.3 & 0.1 & 3.8675 & 9420.2 & 4.4869 & 9415.713 \\
0.3 & 0.2 & 3.8725 & 7443.1 & 3.765 & 7439.335 \\
0.3 & 0.3 & 3.88 & 5698.6 & 3.0767 & 5695.523 \\
0.3 & 0.4 & 3.885 & 4186.8 & 2.4228 & 4184.377 \\
0.4 & 0.1 & 4.1625 & 9420.2 & 5.2647 & 9414.935 \\
0.4 & 0.2 & 4.1675 & 7443.1 & 4.4145 & 7438.686 \\
0.4 & 0.3 & 4.1788 & 5698.6 & 3.6075 & 5694.993 \\
0.4 & 0.4 & 4.1875 & 4186.8 & 2.8412 & 4183.959 \\
\hline \hline
\end{tabular}

Tabel 5.

Hasil Perhitungan Selisih BKA dengan BKB

\begin{tabular}{cccccc}
\hline \hline$\omega$ & $\lambda$ & BKA & BKB & BKA-BKB & $\begin{array}{c}\text { Proses } \\
\text { Mulai } \\
\text { Stabil }\end{array}$ \\
\hline 0.1 & 0.1 & 2.8383 & 0.5722 & 2.2661 & 240 \\
0.1 & 0.2 & 2.3796 & 0.4649 & 1.9147 & 270 \\
0.1 & 0.3 & 1.9418 & 0.3641 & 1.5777 & 286 \\
0.1 & 0.4 & 1.5263 & 0.2737 & 1.2526 & 298 \\
0.2 & 0.1 & 3.6903 & -0.2798 & 3.9701 & 51 \\
0.2 & 0.2 & 3.0976 & -0.2532 & 3.3508 & 39 \\
0.2 & 0.3 & 2.5314 & -0.2255 & 2.7569 & 37 \\
$\mathbf{0 . 2}$ & $\mathbf{0 . 4}$ & $\mathbf{1 . 9 9 5 4}$ & $\mathbf{- 0 . 1 9 5 4}$ & $\mathbf{2 . 1 9 0 8}$ & $\mathbf{3 6}$ \\
0.3 & 0.1 & 4.4869 & -1.0764 & 5.5633 & 43 \\
0.3 & 0.2 & 3.765 & -0.9206 & 4.6856 & 26 \\
0.3 & 0.3 & 3.0767 & -0.7708 & 3.8475 & 23 \\
0.3 & 0.4 & 2.4228 & -0.6228 & 3.0456 & 23 \\
0.4 & 0.1 & 5.2647 & -1.8542 & 7.1189 & 40 \\
0.4 & 0.2 & 4.4145 & -1.5701 & 5.9846 & 22 \\
0.4 & 0.3 & 3.6075 & -1.3016 & 4.9091 & 17 \\
0.4 & 0.4 & 2.8412 & -1.0412 & 3.8824 & 16 \\
\hline \hline
\end{tabular}

Nilai pembobot yang dianggap paling sensitif untuk mendeteksi adanya pergeseran proses adalah $\omega$ dan $\lambda$ yang masing-masing 0.2 dan 0.4. diagram kendali dengan pembobot tersebut menghasilkan proses mulai stabil pada pengamatan ke37. 36 titik yang keluar pada awal proses merupakan keadaan dimana mesin sedang menstabilkan proses setelah digunakan untuk memproduksi produk yang lain sehingga pada saat tersebut belum bisa dilakukan penilaian terhadap baik buruknya proses yang berlangsung. Setelah pengamatan ke-36 tidak terdapat titik yang out of control sehingga dikatakan bahwa proses terkendali secara statistik.

2) Pengendalian Rata-Rata Proses Fase Satu

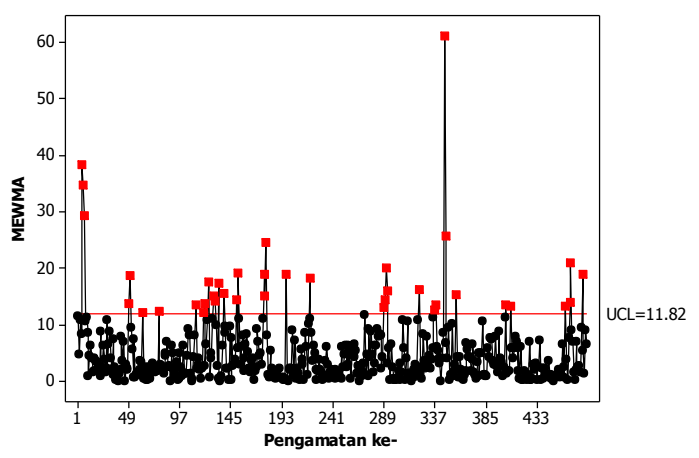

Gambar 2. Diagram Kendali MEWMA dengan $\lambda=0.9$. 
Nilai pembobot yang digunakan pada penelitian ini adalah 0.1 hingga 0.9 dengan jarak antar pembobot sebesar 0.1. Dari sembilan pembobot yang berbeda tersebut, ada salah satu pembobot optimum yang mampu mendeteksi adanya pergeseran proses dalam mean dengan baik. Salah satu pembobot yang digunakan adalah $\lambda=0.9$. hasilnya disajikan pada Gambar 2.

Pemilihan pembobot terbaik untuk diagram kendali $j$ MEWMA didasarkan pada selisih minimum antara nilai titik pengamatan maksimum dan BKA serta lebarnya batas kendali. Berikut disajikan perhitungan untuk masing-masing nilai pembobot.

Tabel 6.

Selisih Antara Pengamatan Maksimum dan BKA

\begin{tabular}{ccccc}
\hline \hline$\lambda$ & BKA & Titik Maksimum & Selisih & Out of control \\
\hline 0.1 & 10.1 & 104.6 & 94.5 & 247 \\
0.2 & 11 & 100.6 & 89.6 & 194 \\
0.3 & 11.4 & 92.5 & 81.1 & 147 \\
0.4 & 11.6 & 80.48 & 68.88 & 119 \\
0.5 & 11.71 & 67.65 & 55.94 & 93 \\
0.6 & 11.77 & 66.72 & 54.95 & 66 \\
0.7 & 11.8 & 66.23 & 54.43 & 57 \\
0.8 & 11.82 & 64.22 & 52.4 & 50 \\
$\mathbf{0 . 9}$ & $\mathbf{1 1 . 8 2}$ & $\mathbf{6 1 . 1 3}$ & $\mathbf{4 9 . 3 1}$ & $\mathbf{3 8}$ \\
\hline \hline
\end{tabular}

Berdasarkan pertimbangan dari resiko produsen dan konsumen, pembobot optimal yang dianggap paling sensitif untuk pengendalian rata-rata proses dengan diagram kendali MEWMA adalah 0.9. meskipun nilai batas kendali atas sebesar 11.82 yang dihasilkan oleh pembobot ini merupakan nilai batas kendali yang paling besar namun tidak berbeda jauh jika dibandingkan dengan nilai batas kendali pada pembobot lainnya. Selain itu, selisih antara titik pengamatan maksimum dan batas kendali atas yang menunjukkan resiko produsen merupakan selisih yang paling kecil yaitu 49.31 dengan titik out of control yang sebanyak 38 .

Pada Gambar 2 diketahui bahwa masih ada data pengamatan yang keluar dari batas kendali sehingga untuk langkah selanjutnya yaitu mengeluarkan data pengamatan yang berada di luar batas kendali, maka syarat utama yang harus dipenuhi adalah diketahuinya faktor penyebab suatu data pengamatan tersebut tidak terkendali. Berikut ini merupakan diagram ishikawa yang merepresentasikan faktor penyebab tidak terkendalinya suatu data pengamatan pada proses produksi kertas koran di PT. Adiprima Suraprinta.

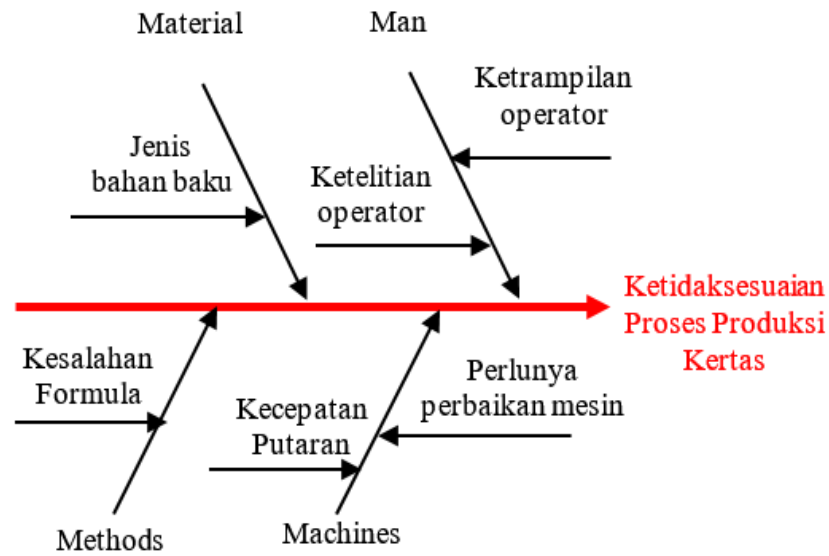

Gambar 3. Diagram Ishikawa proses produksi kertas koran.
Berdasarkan brainstorming yang telah dilakukan dengan pihak produksi, penyebab dari proses yang tidak terkendali disebabkan oleh 4 faktor yaitu Material, Man, Machine dan Methods yang digambarkan melalui diagram ishikawa. Kesalahan terbesar adalah pada faktor material, yaitu jenis bahan baku (waste paper) yang beragam yang akan mempengaruhi kualitas kertas yang dihasilkan. Karena setiap jenis kertas memiliki jenis serat kertas yang berbeda dan tinta yang berbeda. Selanjutnya kesalahan lainnya pada proses produksi adalah faktor mesin yaitu kecepatan putaran mesin agitator tidak sesuai sehingga menyebabkan partikel tinta masih ikut dalam proses. Oleh karena itu perlu adanya perawatan mesin secara berkala agar dapat memproduksi secara maksimal dan produk yang dihasilkan sesuai dengan target perusahaan.

Mesin dapat bekerja berkat adanya operator yang mengoperasikan. Ketrampilan dan ketelitian seorang operator sangat dibutuhkan untuk menunjang kebaikan kinerja mesin. Operator yang kurang teliti saat melakukan setting mesin bisa menyebabkan hasil akhir tidak optimal. Kesalahan pemasukan formula merupakan faktor dari elemen methode. Kesalahan pemasukan formula bahan kimia dan air akan berdampak pada kualitas kertas yang dihasilkan.

Setelah diketahui penyebab tidak terkendalinya suatu data pengamatan pada proses produksi kertas koran dan andaikan pihak perusahaan dapat melakukan proses perbaikan pada faktor penyebab tidak terkendalinya suatu data pengamatan tersebut, maka selanjutnya akan dilakukan perbaikan pada diagram kendali MEWMA dengan cara mengeluarkan pengamatan yang keluar dari batas kendali.

Dari Gambar 4 tersebut diketahui bahwa setelah data yang out of control dikeluarkan terlihat bahwa sudah tidak ada lagi pengamatan yang berada di luar batas kendali, sehingga dapat disimpulkan bahwa setelah dilakukan perbaikan maka rata-rata proses pada fase satu telah terkendali secara statistik

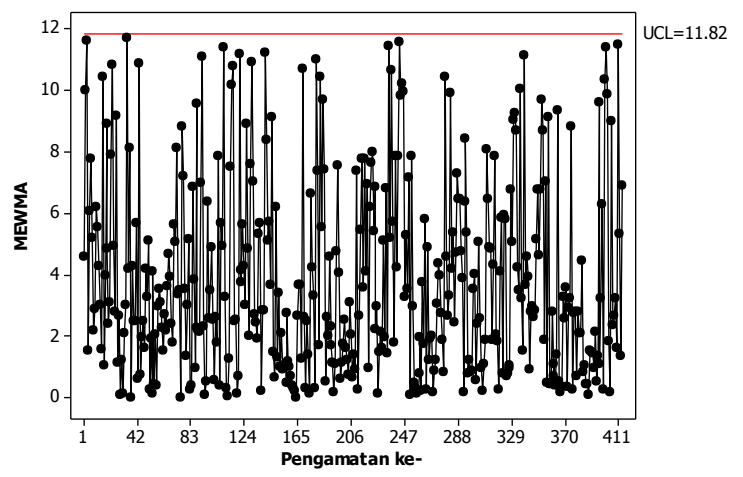

Gambar 4. Diagram Kendali MEWMA dengan $\lambda=0.9$ setelah perbaikan.

3) Pengendalian Variabilitas Proses Fase Dua

Pembobot paling optimum yang dihasilkan pada fase satu kemudian digunakan untuk mengendalikan variabilitas proses pada fase dua yang berlangsung pada bulan Februari sampai Maret 2017 sebanyak 288 data. Hasilnya disajikan pada Gambar 5. 


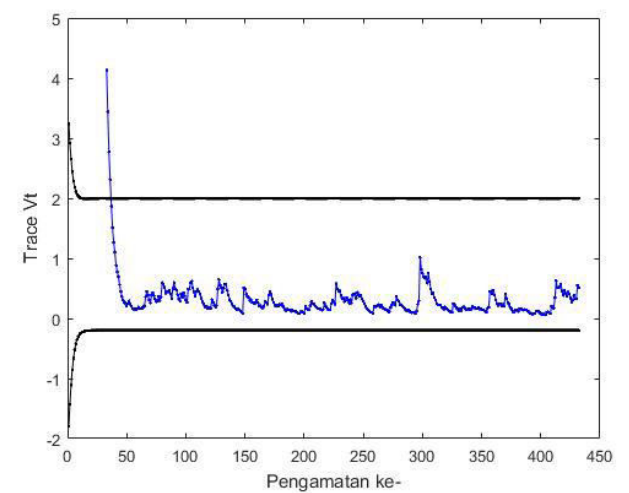

Gambar 5. Diagram Kendali MEWMV Fase Dua dengan $\omega=0.2$ dan $\lambda=0.4$.

Pengendalian variabilitas proses pada fase dua didapatkan ada 36 observasi yang berada di luar batas kendali pada awal proses. Baik buruknya proses dilihat ketika proses mulai stabil, setelah observasi ke-36 tidak ada titik yang berada di luar batas kendali, sehingga dikatakan bahwa proses terkendali secara statistik.

\section{4) Pengendalian Rata-Rata Proses Fase Dua}

Pembobot optimal yang sudah didapatkan pada pengendalian rata-rata proses fase satu yaitu 0.9 selanjutnya akan digunakan untuk mengendalikan rata-rata proses pada fase dua dengan hasil sebagai berikut.

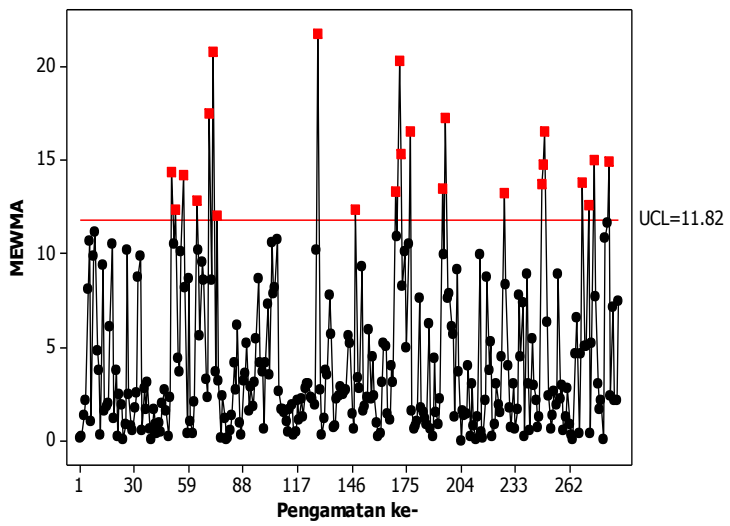

Gambar 6. Diagram Kendali MEWMA Fase Dua dengan $\lambda=0.9$.

Pengendalian rata-rata proses pada fase dua menunjukkan bahwa proses tidak terkendali secara statistik karena terdapat 23 titik pengamatan yang berada di luar batas kendali. Hasil pada fase dua sama tidak baiknya dengan hasil pada fase satu, hal ini disebabkan tidak adanya perbaikan proses yang dilakukan oleh perusahaan.

\section{E. Kapabilitas Proses Produksi Kertas Koran}

Kapabilitas proses digunakan untuk mengetahui kinerja proses secara keseluruhan yang diukur dari keseragaman produk yang dihasilkan. Dikarenakan proses tidak terkendali secara statistik baik untuk variabilitas maupun mean proses maka indeks kapabilitas proses yang digunakan adalah indeks performance process yaitu $\mathrm{MP}_{\mathrm{P}}$ dan $\mathrm{MP}_{\mathrm{pk}}$. Ketika masingmasing nilai tersebut lebih besar dari satu maka dapat dikatakan bahwa proses kapabel. Secara univariat, hasil perhitungan $\mathrm{P}_{\mathrm{P}}$ dan $\mathrm{P}_{\mathrm{pk}}$ adalah sebagai berikut.
Tabel 7.

Kapabilitas Proses Secara Univariat

\begin{tabular}{clll}
\hline \hline Fase & Variabel & $\mathrm{P}_{\mathrm{p}}$ & $\mathrm{P}_{\mathrm{pk}}$ \\
\hline \multirow{2}{*}{ Satu } & Brightness & 0.85 & 0.82 \\
& Opacity & - & 0.93 \\
\multirow{2}{*}{ Dua } & Brightness & 0.77 & 0.73 \\
& Opacity & - & 1.11 \\
\hline \hline
\end{tabular}

Secara univariat, hanya variabel brightness pada fase dua yang menunjukkan akurasi yang baik, karena nilai $\mathrm{P}_{\mathrm{pk}}$ lebih dari satu. Kandungan yang lainnya menunjukkan nilai presisi dan akurasi yang rendah karena nilai $\mathrm{P}_{\mathrm{P}}$ dan $\mathrm{P}_{\mathrm{pk}}$ masih kurang dari satu. Selanjutnya, perhitungan secara univariat ini digunakan untuk menghitung $\mathrm{MP}_{\mathrm{pk}}$ dengan hasil sebagai berikut.

- Fase Satu

$$
\mathrm{MP}_{\mathrm{pk}}=(0.5 \times 0.82)+(0.5 \times 0.93)=0.875
$$

- $\quad$ Fase Dua

$$
\mathrm{MP}_{\mathrm{pk}}=(0.5 \times 0.73)+(0.5 \times 1.11)=0.92
$$

Berdasarkan hasil analisis secara multivariat didapatkan nilai $\mathrm{MP}_{\mathrm{pk}}$ untuk fase satu dan dua berturut-turut sebesar 0.875 dan 0.92, dimana nilai ini lebih kecil dari satu yang menandakan bahwa kinerja proses secara multivariat memiliki tingkat presisi dan akurasi proses tidak baik.

\section{KESIMPULAN}

\section{A. Kesimpulan}

Berdasarkan hasil analisis yang dilakukan pada Bab IV dapat disimpulkan bahwa baik pada fase satu maupun fase dua, variabilitas proses produksi kertas koran terkendali secara statistik sedangkan rata-rata proses produksi tidak terkendali secara statistik. Hal ini dikarenakan pada diagram kendali MEWMA masih terdapat titik yang out of control. Pembobot optimum untuk diagram MEWMV adalah $\omega=0.2$ dan $\lambda=0.4$, dan untuk MEWMA adalah $\lambda=0.9$.

Hasil perhitungan kapabilitas proses pada fase satu maupun fase dua secara multivariat menunjukkan kinerja proses produksi kertas koran terhadap variabel brightness dan opacity pada fase satu maupun fase dua tidak kapabel karena nilai indeks kinerja proses $\mathrm{MP}_{\mathrm{pk}}$ kurang dari satu. Nilai $\mathrm{MP}_{\mathrm{pk}}$ untuk fase satu sebesar 0.875 dan untuk fase dua sebesar 0.92 .

\section{B. Saran}

Dalam melakukan proses produksi kertas koran, PT. Adiprima Suraprinta harus melakukan perbaikan proses karena terdapat produksi kertas koran yang tidak terkendali dalam rata-rata. Selain itu, faktor-faktor penyebab ketidaksesuaian proses produksi kertas harus menjadi prioritas perbaikan sehingga proses produksi kedepannya dapat terkendali dan sesuai dengan yang diharapkan oleh PT. Adiprima Suraprinta.

Penerapan diagram kendali MEWMV dan MEWMA diharapkan dapat menjadi pertimbangan untuk pengendalian proses produksi secara statistik selain hanya memperhatikan produk yang memenuhi batas spesifikasi perusahaan.

\section{DAFTAR PUSTAKA}

Endarwati, "Industri Pulp dan Kertas Indonesia Diproyeksi Tumbuh 4\%," Sindonews, 2017.

[2] D. Montgomery, Introduction to Statistical Quality Control, 6th ed. 
New York: John Wiley \& Sons Inc, 2009.

[3] Singgih, L. Moses, and Renanda., "Pengendalian Kualitas Produk Kertas dengan Menggunakan Pendekatan Six Sigma di Pabrik Kertas Y," Surabaya, 2008.

[4] D. Novitasari, "Pengendalian Kualitas Produk Pakan Ternak di PT. Japfa Comfeed Indonesia Tbk Unit Gedangan," Surabaya, 2016.

[5] D. Morrison, Multivariate Statistical Methods, 3rd ed. New York: Mc Graw Hill Companies, 1990.

[6] S. Shapiro and M. B. Wilk, "An analysis of variance test for normality (complete samples)," Biometrika, vol. 52, no. 3-4, pp. 591-611, 1965.
[7] L. Huwang, Arthur, and Chien-Wei., "Monitoring Multivariate Process Variability for Individual Observations," J. Qual. Technol., vol. 33, pp. 258-278, 2007.

[8] C. A. Lowry, W. H. Woodall, C. W. Champ, and S. E. Rigdon, "A Multivariate Exponentially Weighted Moving Average Control Chart," Technometrics, vol. 34, pp. 46-53, 1992.

[9] S. Raissi, "Multivariate process capability indices on the presence of priority for quality characteristics," J. Ind. Eng. Int., vol. 5, no. 9, p. 2736, 2009. 